\title{
Gambaran histopatologik lambung tikus wistar (Rattus norvegicus) yang diberi perasan umbi bengkuang (Pachyrhizus erosus (L) Urban) setelah induksi aspirin
}

\author{
${ }^{1}$ Debora R. Mentang \\ ${ }^{2}$ Lily L. Loho \\ ${ }^{2}$ Poppy M. Lintong
}

\author{
${ }^{1}$ Kandidat Skripsi Fakultas Kedokteran Universitas Sam Ratulangi Manado \\ ${ }^{2}$ Bagian Patologi Anatomi Fakultas Kedokteran Universitas Sam Ratulangi Manado \\ Email: dmentang11_018@yahoo.com
}

\begin{abstract}
Acute gastritis is an acute inflammation of the gastric mucosal and submucosal. This disease is caused by a variety of factors, one of which is the use of non-steroidal antiinflammatory drugs (NSAIDs) such as aspirin. Aspirin is one of the salicylate group that is irritating to the stomach. Yam stimulate the growth of epithelial cells also repair the surface of cells in the gastric mucosal. This research aims to describe histopathologic Wistar rats were given gastric juice yam tubers after induction aspirin. This is an experimental laboratory study conducted in September 2014 until January 2015 with a sample of 20 Wistar rats were divided into 4 groups. A group given no treatment. Group B was given aspirin $150 \mathrm{mg}$ for 10 days. Group C was given aspirin $150 \mathrm{mg}$ for 10 then given yam tuber juice for 3 days. Group D was given aspirin $150 \mathrm{mg}$ for 10 days and then given pellets for 3 days. Results showed that microscopic pictures of stomach of wistar rats in group $C$ were presented with PMN inflammatory cells fewer than rats in group B and D. Conclusion: Aspirin showed signs of acute gastritis and giving yam tuber juice of showed inflammation-inflammatory less than without giving juice of yam tubers.
\end{abstract}

Keywords: bengkoang, aspirin, acute gastritis

\begin{abstract}
Abstrak : Gastritis akut adalah inflamasi akut pada mukosa dan submukosa lambung. Penyakit ini biasanya disebabkan karena banyak faktor salah satunya yaitu penggunaan obat non steroid anti inflamasi (NSAID) seperti aspirin. Aspirin merupakan salah satu dari golongan salisilat yang bersifat iritatif terhadap lambung. Bengkuang merangsang pertumbuhan sel-sel epitel juga perbaikan permukaan sel pada mukosa lambung. Penelitian ini bertujuan untuk mengetahui gambaran histopatologik lambung tikus wistar yang diberi perasan umbi bengkuang setelah induksi aspirin. Penelitian ini bersifat eksperimental laboratorik yang dilakukan pada bulan September 2014 sampai Januari 2015 dengan sampel 20 ekor tikus wistar yang dibagi dalam 4 kelompok perlakuan. Kelompok A tidak diberikan perlakuan. Kelompok B diberikan aspirin $150 \mathrm{mg}$ selama 10 hari. Kelompok C diberikan aspirin $150 \mathrm{mg}$ selama 10 kemudian diberikan perasan umbi bengkuang selama 3 hari. Kelompok D diberikan aspirin 150 mg selama 10 hari kemudian diberikan pelet selama 3 hari. Hasil penelitian ini menunjukkan bahwa gambaran mikroskopik lambung tikus wistar pada kelompok C terdapat sel-sel radang PMN yang lebih sedikit dibandingkan dengan kelompok B dan D. Simpulan: Pemberian aspirin menunjukkan tanda-tanda gastritis akut dan pemberian perasan umbi bengkuang menunjukkan radang-radang lebih sedikit dibandingkan tanpa pemberian perasan umbi bengkuang.
\end{abstract}

Kata kunci: bengkuang, aspirin , gastritis akut 
Bengkuang yang dikonsumsi masyarakat pada umumnya adalah bagian umbinya. Umbi ini juga digunakan sebagai bahan dasar obat tradisional, salah satunya untuk mengurangi kadar asam lambung. Bengkuang merangsang pertumbuhan selsel epitel juga perbaikan permukaan sel pada mukosa lambung. ${ }^{1,2,3}$

Aspirin atau acetyl salicylic acid yang termasuk dalam golongan salisilat merupakan salah satu jenis non steroidal anti-inflammatory drugs atau NSAIDs yang banyak digunakan pada pengobatan nyeri ringan sampai sedang juga mempunyai efek antipiretik, anti inflamasi serta anti koagulan. Beberapa penelitian menggunakan aspirin sebagai bahan penginduksi gastritis pada hewan coba. Aspirin bekerja menghambat enzim siklooksigenase 1 dan 2 sehingga kadar prostaglandin (PG) menurun. Konsumsi secara oral aspirin mengakibatkan peningkatan sekresi asam lambung dan penurunan sekresi mukus lambung sehingga dapat menyebabkan iritasi pada lapisan mukosa lambung. Aspirin menyebabkan pengelupasan sel epitel permukaan dan mengurangi sekresi mukus yang merupakan barier protektif terhadap asam. Selain itu aspirin dapat menekan produksi prostaglandin dan tromboksan.,

Gastritis adalah proses inflamasi pada lapisan mukosa dan submukosa lambung dan secara histopatologik dapat dibuktikan dengan adanya infiltrasi sel- sel radang pada daerah tersebut. ${ }^{7,8}$

Berdasarkan hal-hal tersebut maka peneliti tertarik untuk melakukan penelitian mengenai gambaran histopatologik lambung tikus wistar yang diberi perasan umbi bengkuang setelah induksi aspirin.

\section{METODE PENELITIAN}

Penelitian ini adalah penelitian eksperimental laboratorik. Penelitian dilakukan di Laboratorium Patologi Anatomi Fakultas Kedokteran Universitas Sam Ratulangi Manado dengan rentang waktu sekitar September sampai Januari 2014. Alat dan bahan yang digunakan antara lain blender, kain kasa/saringan, sonde, disposable $1 \mathrm{ml}$, glass object, kamera mikroskop digital, perasan umbi bengkuang, pellet AD2, aspirin $80 \mathrm{mg}$.

Subjek penelitian ini adalah 20 ekor tikus wistar dalam keadaan sehat. Kelompok kontrol terdiri dari 5 ekor. Kelompok perlakuan terdiri dari 15 ekor yang dibagi dalam 3 kelompok perlakuan.

a. Kelompok A (kontrol negatif) : kelompok ini terdiri dari 5 ekor tikus wistar yang tidak diberi aspirin maupun bengkuang. Tikus wistar diberi makanan pelet setiap hari selama 10 hari. Pada hari ke-11 tikus wistar diterminasi untuk diambil lambungnya yang kemudian diamati secara makroskopik dan mikroskopik.

b. Kelompok B : kelompok ini terdiri dari 5 ekor tikus wistar yang diberi aspirin 150 mg/kgBB selama 10 hari. Pada hari ke-11 tikus wistar diterminasi untuk diambil lambungnya yang kemudian di amati secara makroskopik dan mikroskopik.

c. Kelompok C : kelompok ini terdiri dari 5 ekor tikus wistar yang diberi aspirin $150 \mathrm{mg} / \mathrm{kgBB}$ selama 10 hari kemudian dilanjutkan dengan pemberian bengkuang $60 \mathrm{mg}$ (2x sehari) selama 3 hari. Pada hari ke-14 tikus wistar diterminasi untuk diambil lambungnya yang kemudian diamati secara makroskopik dan mikroskopik.

d. Kelompok D : kelompok ini terdiri dari 5 ekor tikus wistar yang diberi aspirin $150 \mathrm{mg} / \mathrm{kgBB}$ selama 10 hari lalu diberikan pelet biasa selama 3 hari. Pada hari ke-14 tikus wistar diterminasi untuk diambil lambungnya yang kemudian diamati secara makroskopik dan mikroskopik. Kemudian diamati secara makroskopik dan mikroskopik.

\section{HASIL PENELITIAN \\ Gambaran makroskopik}

Pengamatan secara makroskopik dimulai pada saat otopsi melalui pengamatan dan pengukuran, dimensi, berat, konsistensi serta warna lambung. (Tabel 1) (Gambar 1). 
Tabel 1. Warna, konsistensi dan berat lambung tikus wistar

\begin{tabular}{ccccc}
\hline Wistar & Perlakuan & Warna & Konsistensi & Berat(gram) \\
\hline & & Merah muda & Lunak & 3,20 \\
A3 & Kelompok Kontrol & Merah muda & Lunak & 3,12 \\
A4 & Merah muda & Lunak & 3,50 \\
A5 & & Merah pucat & Lunak & 2,60 \\
B1 & & Merah pucat & Lunak & 2,40 \\
B2 & \multirow{2}{*}{ Aspirin 150 mg/hari } & Merah pucat & Lunak & 2,60 \\
B3 & Merah pucat & Lunak & 2,31 \\
B4 & & Merah pucat & Lunak & 2,30 \\
B5 & & Lunak & 2,95 \\
C1 & Aspirin 150 mg dilanjutkan & Merah muda & Lunak & 2,80 \\
C2 & dengan perasan umbi & Merah muda & Lunak & 2,85 \\
C3 & bengkuang 60 mg & Merah muda & Lunak & 2,10 \\
C4 & & Merah muda & Lunak & 2,15 \\
C5 & & Merah muda & Lunak & 3,40 \\
D2 & Aspirin 150 mg dilanjutkan & Merah muda & Lunak & 2,47 \\
D3 & dengan pelet & Merah muda & Lunak & 2,90 \\
D4 & & Merah muda & Lunak & 2,92 \\
D5 & & Merah muda &
\end{tabular}

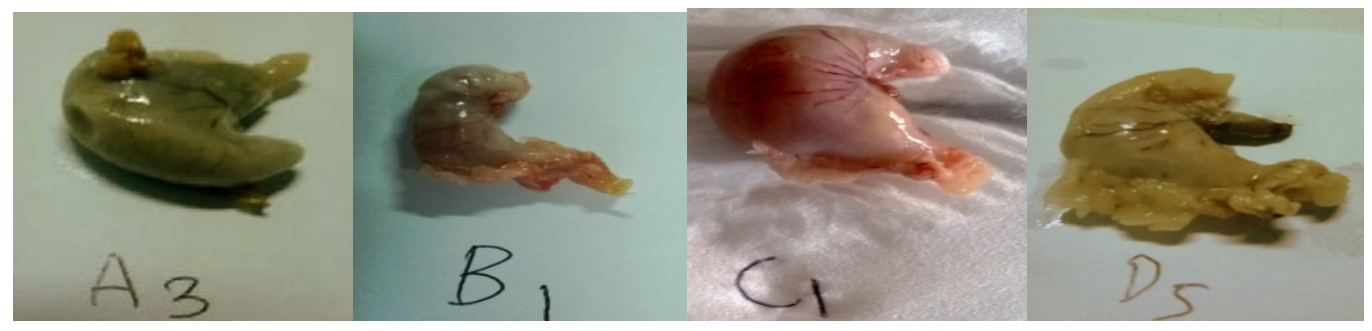

Gambar 1. Gambaran makroskopik lambung tikus wistar

\section{Gambaran mikroskopik}

\section{Tikus wistar kelompok kontrol}

Pada tikus wistar kelompok kontrol menunjukkan dinding lambung yang normal, tampak lapisan mukosa, submukosa, muskularis dan serosa yang normal. Tidak terdapat sel-sel radang. (Gambar 2).

\section{BAHASAN}

Pada kelompok kontrol negatif terlihat gambaran lambung normal. Pada kelompok perlakuan pemberian aspirin $150 \mathrm{mg}$ per hari selama 10 hari gambaran makroskopik lambung tampak agak pucat. Selain itu dinding lambung juga tampak sedikit menipis. Hal ini terjadi karena aspirin menghambat sintesis prostaglandin sehingga aliran darah pada daerah mukosa menjadi terganggu, dan juga menyebabkan hilangnya lapisan mukus yang melindungi mukosa lambung. ${ }^{6,20}$ Gambaran mikroskopiknya menunjukkan peradangan akut pada daerah mukosa dan submukosa lambung di seluruh bagian lambung yang di tunjukkan dengan adanya infiltrasi sel PMN yang banyak. Hal ini sesuai kepustakaan yang mengatakan bahwa aspirin dapat merusak epitel mukosa secara langsung serta dapat mengurangi sekresi ion bikarbonat dan sekresi mukus. Akibatnya faktor pertahanan dari lambung terganggu dan terjadilah sutu proses radang akut (gastritis akut) yang ditandai dengan adanya sel-sel PMN pada daerah mukosa. ${ }^{7,13}$

Pada kelompok wistar dengan perlakuan pemberian aspirin $150 \mathrm{mg}$ 
selama 10 hari dilanjutkan dengan pemberian perasan bengkuang $60 \mathrm{mg}$ selama 3 hari secara makroskopik tampak berwarna merah muda. Gambaran mikroskopiknya masih tampak adanya selsel PMN di lapisan mukosa maupun submukosa bagian bawah namun dalam jumlah yang lebih kurang dibandingkan kelompok B (Gambar 2). Ini menunjukkan bahwa perasan umbi bengkuang memiliki efek proteksi terhadap lambung. Rasa manis dari oligosakarida dan kandungan asam askorbat sebagai sumber antioksidan untuk menghalangi radikal bebas dan mencegah kerusakan oksidatif membran sel tubuh yang diakibatkan oleh aspirin.

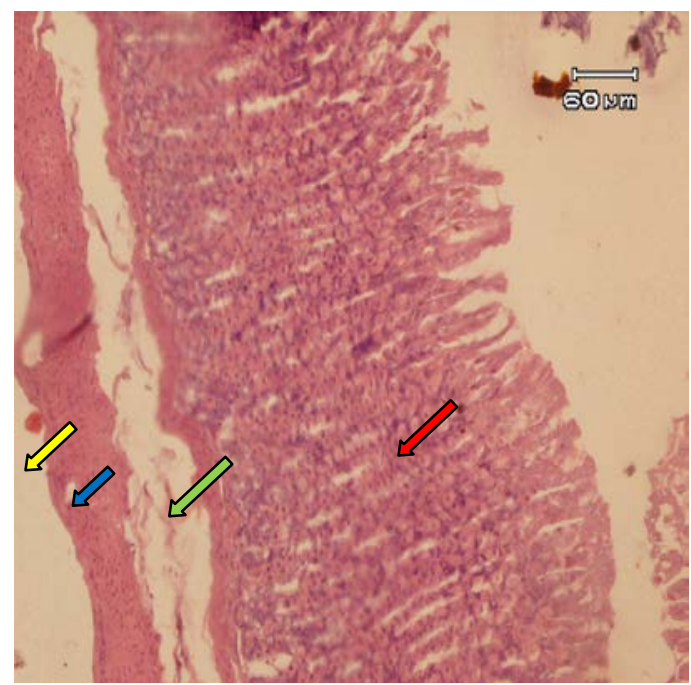

Gambar 2. Gambaran mikroskopik lambung tikus wistar yang diberikan makanan pelet standar selama 10 hari. Tampak daerah mukosa dengan kelenjar-kelenjar (panah merah), submucosa (panah hijau), muskularis (panah biru) dan serosa (panah kuning) yang normal. Pembesaran 10 x 20.

\section{Tikus wistar kelompok perlakuan B}

Pada tikus wistar kelompok perlakuan B yang diberi perlakuan aspirin selama 10 hari menunjukkan jaringan lambung dengan infiltrasi sel-sel radang polymorphonuclear (PMN) pada daerah lamina propria mukosa, submukosa, dan muskularis mukosa (Gambar 3).

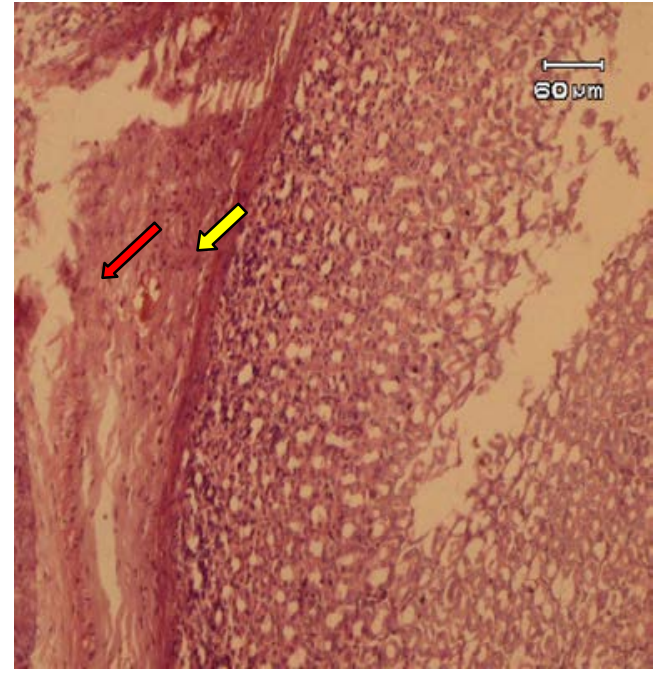

Gambar 3. Gambaran mikroskopik lambung tikus wistar yang diberi aspirin selama 10 hari. Tampak banyak sel-sel radang PMN (panah kuning) di submukosa dan pembuluh darah melebar berisi eritrosit (panah merah) pada submukosa. Pembesaran 10 x 10.

\section{Tikus wistar kelompok perlakuan C}

Pada tikus wistar kelompok perlakuan C yang diberi perlakuan aspirin selama 10 hari, kemudian dilanjutkan dengan perasan umbi bengkuang selama 3 hari. Kelompok ini menunjukkan perbaikan struktur lambung, jika dibandingkan dengan kelompok perlakuan B. Sel-sel radang limfosit dan PMN mulai berkurang dan tidak menyeluruh, edema mulai berkurang. (gambar 4).

\section{Tikus wistar kelompok perlakuan D}

Pada tikus wistar kelompok perlakuan D yang diberi perlakuan aspirin selama 10 hari, kemudian dilanjutkan pemberikan pelet biasa selama 3 hari menunjukkan masih terdapat sel-sel radang PMN dan edema di bagian bawah mukosa lambung. (gambar 5).

Juga asam askorbat memperbaiki serabut kolagen yang terdapat pada lamina propria lambung karena berfungsi sebagai kofaktor pada alfa-hidroksilasi prokolagen. Hasilnya bengkuang mengurangi peradangan pada permukaan mukosa lambung dan merangsang pertumbuhan selsel epitel. ${ }^{4,24,26}$ 


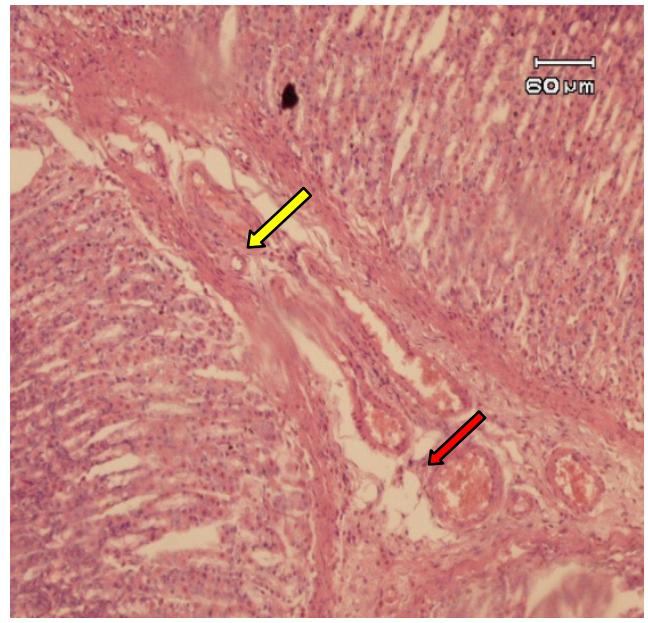

Gambar 4. Gambaran mikroskopik lambung wistar yang diberikan aspirin $150 \mathrm{mg}$ selama 10 hari dilanjutkan pemberian perasan umbi bengkuang $60 \mathrm{mg}$ selama 3 hari. Tampak sel sedikit radang PMN dan edema (panah kuning). Tampak pembuluh darah yang berisi eritrosit pada submukosa (panah merah). Pembesaran $10 \times 10$.

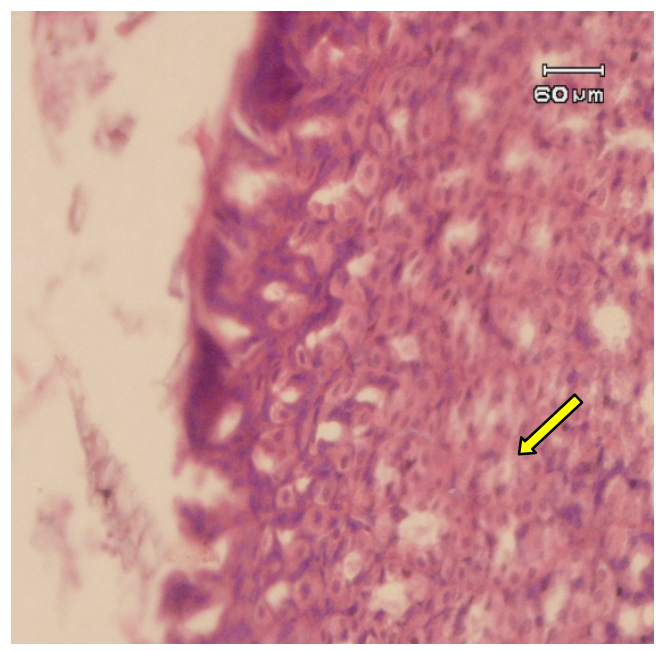

Gambar 5. Gambaran mikroskopik lambung wistar yang diberikan aspirin $150 \mathrm{mg}$ selama 10 hari dilanjutkan pelet selama 3 hari. Sedikit radang di mukosa bagian bawah (panah kuning). Pembesaran 10 x 40.

Pada kelompok wistar dengan perlakuan pemberian aspirin $150 \mathrm{mg}$ selama 10 hari kemudian dilanjutkan dengan pemberian pellet standart selama 3 hari menunjukkan secara makroskopik tampak berwarna merah muda. Gambaran mikroskopiknya masih terdapat sedikit selsel radang PMN di daerah mukosa bagian bawah dan submukosa lambung. Berkurangnya sel radang pada kelompok ini lebih lambat dibanding kelompok C. Antara kelompok C dan D mempunyai perbedaan yang cukup berarti dalam hal jumlah sel-sel radang PMN pada lambung tikus wistar. Ini disebabkan karena pada kelompok $\mathrm{C}$ diberikan perasan umbi bengkuang sehingga penyembuhan lebih cepat dan bermakna. Dibandingkan kelompok D yang hanya diberikan pellet standart, menunjukkan masih tampak selsel radang PMN dan edema tetapi sedikit di submukosa.

\section{SIMPULAN}

Berdasarkan hasil penelitian yang didapat disimpulkan bahwa pemberian aspirin menunjukkan tanda-tanda gastritis akut dan pemberian perasan umbi bengkuang menunjukkan radang-radang lebih sedikit dibandingkan tanpa pemberian perasan umbi bengkuang.

\section{DAFTAR PUSTAKA}

1. Karuniawan A, Wicaksana N. Genetic relationships of yam bean pachyrhizus erosus population based on morphological characters of flowers and leaves. 2006. Bul. agron. (34) (2) $98-105$.

2. Lukitaningsih E. Phytosterol content in bengkoang (pachyrhizus erosus). Pharmacon. Desember 2012; Vol.3 no.2: 47-54.

3. Wongsowijoyo S. Umbi-umbi berkhasiat obat. 2014. http://www.leutikaprio.com/main/me dia/sample/article.pdf Diakses 16 sept 2014

4. Laboratorium Klinik Prodia. Bengkuang yang kerap dilupakan. http://prodia.co.id/tipskesehatan/bangkuang-yang-kerapdilupakan/pdf Diakses 27 sep 2014

5. Sudoyo AW, Setiyohadi B, Alwi I, Simadibrata KM, Setiadi S. Buku ajar ilmu penyakit dalam edisi 5 jilid 1. Interna publishing; 2009. h. 50912.

6. Farmakologi dan terapi edisi 5. Jakarta: Departemen farmakologi dan teraupetik fakultas kedokteran UI; 
2007; 3: 230-231, 234-237

7. Kumar V, Cotran RS, Robbins SL. Buku ajar patologi edisi 7 volume 2. EGC; 2007; 2: 36-46

8. Robbins, Kumar, Abbas, Lotran. The oral cavity and the gastrointestinal tract. In: Schmitt W, Gruliow R, editors. Basic of pathology. 8th ed. American: Saunder elsevier; 2010. p. 591-3.

9. Widjaja H. Anatomi abdomen. Jakarta: EGC; 2008. h. 53-4.

10.Primiani CV. Dinamika senyawa daidzein umbi bengkuang (pachyrhizus erosus) dalam darah serta potensinya pada tikus putih betina. Madiun: IKIP PGRI.

http://download.portalgaruda.org/artic le.com. Diakses 16 sep 2014

11.Panggabean FDM, Mawarni L, Chairun N. Respon pertumbuhan dan produksi bengkuang ( Pachyrhizus erosus (L.) urban ) terhadap waktu pemangkasan dan jarak tanam. Jurnal online Argoekoteknologi. Maret 2014. Vol.2,No.2: 702-711.

12.Kahle W, Leonhardt $H$, PlatzernW. Atlas berwarna dan teks anatomi manusia. Edisi 6. Jakarta: Hipokrates; 1997. h. 212-16.

13.Kumar, Cotran, Robbins. Sistem pencernaan. Dalam: Hartanto $\mathrm{H}$, Darmaniah N, Asroruddin M, (editor). Buku ajar patologi. Edisi 7. Jakarta: Penerbit kedokteran EGC; 2007. h. 624-6.

14.Loho L. Patologi saluran pencernaan. Manado: Bagian patologi anatomi fakultas kedokteran Universitas samratulangi, 2002. h. 21-9.

15.Komposisi kimia buah bengkuang. (http://repository.usu.ac.id/bitstream/ 123456789/31383/4/Chapter\%20II.pd f Diakses 12 sept 2014

16.Irianto K. Anatomi dan fisiologi. Bandung: Alfabeta; 2013. h.211-12

17. Mitchell, Kumar, dkk. Buku saku dasar patologis penyakit. Edisi 7. Jakarta: EGC; 2008. p.474.

18.Chandrasoma $P$, Taylor CR. Respon peradangan akut. Jakarta. EGC; 2005. h. 34-5.

19.Turner JR. The gastrointestinal tract. In: Kumar V, Abbas F, Robbins SL, Cotran pathologic basic of disease. 8th ed. New york: Saunders elsevier; 2010. p. 775

20.Mustaba R, Winaya IO, I Ketutberata. Studi histopatologik lambung pada tikus putih yang diberi madu sebagai pencegah ulkus lambung yang diinduksi aspirin. Indonesia Medicus Veterinus. 2012 1(4): 471-482.

21.Setyadi AW, Junianto F, Yulianti E. Pengaruh sari bengkuang (pachyrhizus erosus) terhadap penurunan kolesterol pada tikus putih (rattus norvegicus) dilaboratorium kimia Universitas Muhammadiyah Malang. Kediri. http://stikesbmpare.ac.id/jurnal/file/JournalP3.pdf Diakses 16 sept 2014

22.Aspirin. USU, malang. [cited 2014 oct 12]. Available

from:http://repository.usu.ac.id/bitstre am/123456789/38265/4/Chapter\%20I I.pdf

23.Sepulveda AR, Patil M. Practical approach to the pathologic diagnosis of gastritis. Arch Pathol Lab Med. Oct 2008;132(10):1586-93.

24.Windriyati YN, Wahyuningrum DP, Murukmihadi M. Pengaruh perbedaan konsentrasi ekstrak etanolik umbi bengkuang (Pachyrrhizus erosus, Urb) dalam sediaan krim terhadap sifat aslinya. Jurnal ilmu farmasi dan klinik. Juni 2007 vol.4 No.1 http://publikasiilmiah.unwahas.ac.id/i ndex.php/ilmuFarmasidanklinik/articl e/view/830 diakses 16 okt 2014

25.Kumar, Cotran, Robbins. Pemulihan Jaringan. Dalam: Hartanto $\mathrm{H}$, Darmaniah N, Asroruddin $\mathrm{M}$, (editor). Buku Ajar Patologi (Edisi Ketujuh). Jakarta: Penerbit Kedokteran EGC, 2007; p.78-81.

26. Wimala M. Penetapan kadar inulin dalam ekstrak air umbi bengkuang (pachyrhizus erosus L.) dari beberapa daerah di Jawa Timur berdasarkan perbedaan ketinggian dengan metode KLT densitometri. Jember.http://repository.unej.ac.id/bit stream/handle/123456789/60327/Mar izka\%20Wimala\%20\%20102210101003_1.pdf Diakses 5 mar 2015 